\title{
Broadening and Deepening: Soy Expansions in a World- Historical Perspective
}

\author{
Ernst Langthaler ${ }^{1}$
}

\begin{abstract}
This article assesses the ongoing South American soy expansion from a world-historical perspective, comparing the case of Brazil with the cases of China and the USA. For this purpose, it applies the concept of commodity frontier, involving both external and internal modes of capitalist incorporation. The Chinese soy expansion (1900s-1930s) shows a predominant shift of the external frontier, associated with the peasant mode of farming. The US soy expansion (1930s-1970s) represents a predominant shift of the internal frontier, connected to the entrepreneurial mode of farming. The Brazilian soy expansion (1970s-2010s) reveals a flexible combination of extensive and intensive frontier shifts, corresponding with the capitalist mode of farming. These commodity booms were driven not only by nation states, capitalist enterprises and social movements, but also by the potentials and limitations of the soybean plant itself. Shifts of commodity frontiers often disrupted society and nature and, hence, were contested among diverse actors, both human and non-human.
\end{abstract}

Keywords: Soybean; Soy Expansion; Commodity Frontier; Mode of Farming; China, USA, Brazil. 
$\mathrm{W}$ are witnessing an unprecedented soy expansion in South America. Soybean harvests in Argentina, Bolivia, Brazil, Paraguay, and Uruguay skyrocketed from 1.6 megatons (mt) in 1970 to $184 \mathrm{mt}$ in 2017. Among the countries of "soylandia," Brazil stands out as a soy powerhouse of global importance: In 2017, it produced $115 \mathrm{mt}$ of soybeans, ranking second after the USA (120 mt) and ahead of Argentina (55 mt), China $(13 \mathrm{mt})$, and India $(11 \mathrm{mt})^{2}$. Conventional accounts often frame the Brazilian soy expansion as an economic success story, emerging in a liberalized political framework, without reference to its impacts on society and nature. However, critical studies emphasize rising economic inequality, businessfriendly state regulation as well as severe socio-natural problems caused by the disruption of peasant communities and near-natural biomes ${ }^{3}$.

From a world-historical perspective, the soy expansion in the Southern Cone is by no means unique. Before the emergence of "soylandia," soy as a global commodity had already expanded in other world regions: first, in northeastern China from the 1900s to the 1930s and, next, in the USA from the 1930s onwards. This article aims at comparing soy expansions in China, the USA and Brazil, thereby integrating the ambivalent story of South American "soylandia" into world history ${ }^{4}$. For this purpose, it investigates these cases with reference to the concept of commodity frontier. Wallerstein's related concept of commodity chain, defined as "a network of labor and production processes whose end result is a finished commodity," ${ }^{5}$ has been a pillar of world-systems analysis for decades. Since its reconceptualization as global commodity chain, global value chain, and global production network ${ }^{6}$, this approach has met some criticism: first, as a world-systemic concept, it tends to disregard the interaction between social actors on regional and local scales ${ }^{7}$; second, as a social-

\footnotetext{
2 "Faostat," Food and Agriculture Organization, 2020, http://www.fao.org/faostat.

3 Herbert S. Klein and Francisco Vidal Luna, Feeding the World: Brazil's Transformation into a Modern Agricultural Economy (Cambridge: Cambridge University Press, 2018); Antonio Augusto Rossotto loris, Agribusiness and the Neoliberal Food System in Brazil: Frontiers and Fissures of Agro-Neoliberalism (Abingdon, Oxon / New York, NY: Routledge, Taylor \& Francis Group, 2018).

${ }^{4}$ Ernst Langthaler, "Gemüse Oder Ölfrucht? Die Weltkarriere Der Sojabohne Im 20. Jahrhundert," in Umkämpftes Essen: Produktion, Handel Und Konsum von Lebensmitteln in Globalen Kontexten, ed. Cornelia Reiher and Sarah Ruth Sippel (Göttingen: Vandenhoeck \& Ruprecht, 2014), $41-$ 66, https://doi.org/10.13109/9783666301704.41; Christine M. Du Bois, The Story of Soy (London: Reaktion Books, 2018).

5 Terence K. Hopkins and Immanuel Wallerstein, "Commodity Chains in the World-Economy Prior to 1800," Review (Fernand Braudel Center) 10, no. 1 (1986): 159, https://www.jstor.org/stable/40241052.

6 Jennifer Bair, Frontiers of Commodity Chain Research (Stanford, California: Stanford University Press, 2008).

7 Thomas D. Hall, "Puzzles in the Comparative Study of Frontiers: Problems, Some Solutions, and Methodological Implications," Journal of WorldSystems Research 15, no. 1 (2009): 25-47, https://doi.org/10.5195/jwsr.2009.332.
} 
scientific concept, it tends to disregard the natural relations of capitalist societies, i.e. the exploitation of both labor and nature ${ }^{8}$.

The concept of commodity frontier, introduced by Moore, confronts these criticisms. It reaches beyond Turner's classical "frontier thesis," arguing that the frontier experience of white settlers shaped collective identity in nineteenth-century North America9. As "a zone beyond which further expansion is possible"10, the commodity frontier involves, first, the more or less contested places of incorporation into the space of the capitalist world-system and, second, the intersection of society and nature ("socio-nature") in the regulated accumulation of value along the commodity chain. Accordingly, world history as conceived by world-systems analysis extends to "world ecology, joining the accumulation of capital, the pursuit of power, and the co-production of nature in dialectical unity"11. Following Ricardo's classical economics $^{12}$, this article distinguishes between external frontiers as zones of the extensive incorporation ("broadening") of new spaces (e.g. through conversion of grasslands into fields) and internal frontiers as zones of the more intensive incorporation ("deepening") of already commodified spaces (e.g. through application of productive technologies). In historical reality, commodity frontiers expand as mixtures of these ideal types, ranging between predominantly extensive and intensive modes of incorporation into regimes of capitalist accumulation and regulation ${ }^{13}$. As revealed by the following sections, the three regional cases under investigation represent quite different modes of commodity frontier expansion.

\footnotetext{
8 Jason W. Moore, Capitalism in the Web of Life: Ecology and the Accumulation of Capital (London, New York: Verso, 2015), 13-38.

${ }^{9}$ Frederick J. Turner, The Frontier in American History (Norderstedt, Germany: BoD - Books on Demand, 2012).

10 Jason W. Moore, "Sugar and the Expansion of the Early Modern World-Economy: Commodity Frontiers, Ecological Transformation, and Industrialization," Review (Fernand Braudel Center) 23, no. 3 (2000): 412, https://www.jstor.org/stable/40241510.

${ }^{11}$ Moore, Capitalism in the Web of Life: Ecology and the Accumulation of Capital, 15.

12 Henry Willebald and Javier Juambeltz, "Land Frontier Expansion in Settler Economies, 1830-1950: Was It a Ricardian Process?," in Agricultural Development in the World Periphery, ed. Vicente Pinilla and Henry Willebald (Cham: Springer International Publishing, 2018), 446, https://doi.org/10.1007/978-3-319-66020-2_17.

13 Jon D. Carlson, "Broadening and Deepening: Systemic Expansion, Incorporation and the Zone of Ignorance," Journal of World-Systems Research 7, no. 2 (2001): 225-63, https://doi.org/10.5195/jwsr.2001.180; Andrea Komlosy, "Kapitalismus Als Frontier: Die Verwandlung von Kulturen in Rohstofflieferanten," in Rohstoffe Und Entwicklung. Aktuelle Auseinandersetzungen Im Historischen Kontext, ed. Karin Fischer, Johannes Jäger, and Lukas Schmidt (Wien: New academic press, 2016).
} 


\section{EXTERNAL SOY EXPANSION IN CHINA, 1900s-1930s}

Northeast China ("Manchuria") emerged as big player in the world market of soy products at the beginning of the twentieth century ${ }^{14}$. Its supply of soybeans, driven by demand for cake in Japan as well as for oil in China and Europe, took off in the late 1900s and peaked in the early 1930s, before political turmoil, economic crisis and natural adversities terminated it (Figure 01). Available data suggest that the 98 percent increase in soybean production from 1924 to 1931 resulted solely from the enlargement of cultivated land by 151 percent, since yields per unit of land, initially amounting to 1.6 tons per hectare, steadily declined by 21 percent. The doubling of land devoted to soybeans involved the conversion of near-natural grasslands and extensive farmland on the Manchurian plain into fields used more intensively. Declining land productivity probably reflected nutrient mining on existing fields and ploughing-up poorer soils at marginal locations. Thus, soy expansion in Manchuria predominantly moved ahead along the external commodity frontier. Throughout this period, soybeans occupied a central place in Manchuria, accounting for about three quarters of total exports ${ }^{15}$.

Manchuria, the region the Chinese call Dongbei or "the Northeast," comprising the three provinces of Liaoning, Jilin, and Heilongjiang, ranked first among the incorporated territories of the Chinese empire until the nineteenth century. In political terms, the region at the intersection of China, Russia, Korea, and Japan represented the "cockpit of Asia." In economic terms, it emerged as Beijing's breadbasket due to the rich quantity and quality of land reserves and the favorable monsoon climate (warm, wet summers and cold, dry winters) in the Manchurian plain. Nonetheless, Manchuria's rise to political and economic importance has been an issue of historiographical debate. While some authors adopt Turner's classical "frontier thesis," arguing that the transformation of wilderness into civilization in the periphery

\footnotetext{
${ }^{14}$ Ines Prodöhl, "Versatile and Cheap: A Global History of Soy in the First Half of the Twentieth Century," Journal of Global History 8, no. 3 (2013): 461-82, https://doi.org/10.1017/S1740022813000375; David Wolff, "Bean There: Toward a Soy- Based History of North East Asia," The South Atlantic Quarterly, 99, no. 1 (2000): 241-52.

15 Data source: Johannes Langenberg, Die Bedeutung Der Sojabohne in Der Weltwirtschaft (Pinneberg: Beig, 1929), 20; John R. Stewart, "The Soya Bean and Manchuria," Far Eastern Survey 5, no. 21 (1936): 221-26, https://doi.org/10.2307/3021359; G. F. Deasy, "The Soya Bean in Manchuria," Economic Geography 15, no. 3 (1939): 303-10, https://doi.org/10.2307/141549; Kang Chao, The Economic Development of Manchuria (Ann Arbor, Ml: University of Michigan Press, 1983), 44, https://doi.org/10.3998/mpub.19151.
} 
by the imperial core shaped Chinese collective identity as a whole, others conceive of the region as a "middle ground," where the interaction of various social groups and landscapes shaped a new borderland culture. Reardon-Anderson rejects both interpretations by arguing that Manchuria experienced the "transplantation of institutions and practices previously established in China proper," thus resulting in "growth without development." Accordingly, the tension between the densely populated, land-short heartland of China and the sparsely populated, land-rich borderland of Manchuria pulled people from the south towards land in the north, thereby transplanting the conventional way of life beyond the Great Wall ${ }^{16}$.

Figure 01. Soy expansion in Northeast China, 1906-1942.

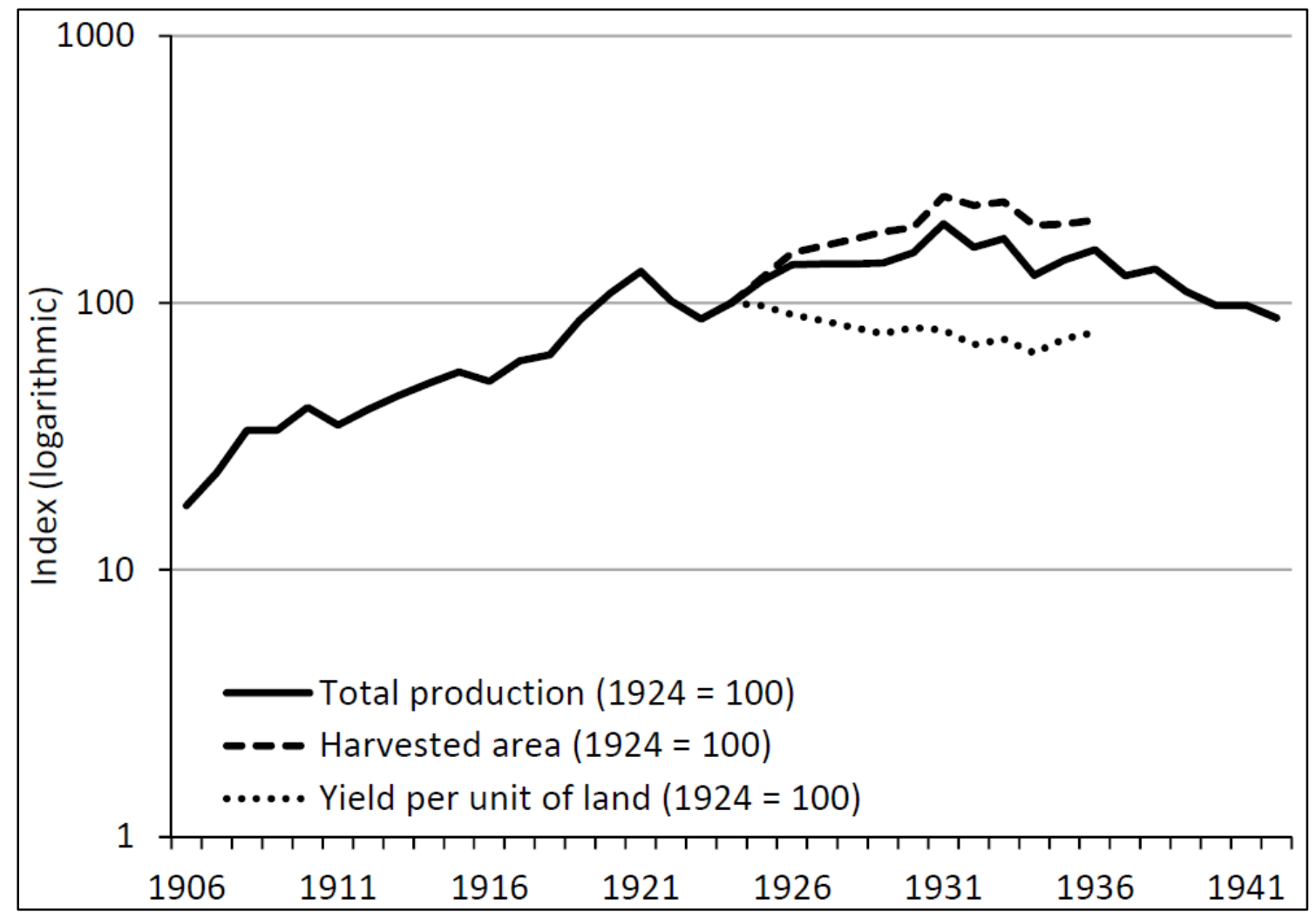

Data source: see ref. 15

In the mid-nineteenth century, the Qing dynasty began to promote the settlement of Han-Chinese people as well as the reclamation and cultivation of land in their homeland where immigration was formerly prohibited. For this purpose, the Manchu rulers abandoned the manorial system and offered land for lease and sale. This decision was taken with two goals: to raise imperial revenues for financing rising

16 James Reardon-Anderson, Reluctant Pioneers: China's Expansion Northward, 1644-1937 (Stanford, California: Stanford University Press, 2005), $2-10$. 
military efforts through the lease and sale of public land and the taxation of privatized farmland; and to strengthen the empire's defense against Russian (and later also Japanese) claims by settling a larger and more permanent population on the borders ${ }^{17}$. As debts and threats worsened at the turn of the century, the government reinforced the reclamation and cultivation of land in the northeast provinces by the "New Policies" of 1902. This initiative coincided with the opening of railroads through Manchuria in 1903 - most importantly, the Chinese Eastern Railway, running east to west from Siberia via Harbin to Vladivostok, and the South Manchuria Railway, connecting north and south from Harbin via Changchun to Dairen. While initially both lines were in Russian hands, the track section between Changchun and Dairen came under Japanese control following the Russo-Japanese War of 1904/05. Consequently, the exploitation of Manchuria's rich resources involved foreign imperialist powers and commercial enterprises, culminating in the Japanese occupation of 1931 (the "Manchurian Incident"). As famine and warlordism spread throughout China in the late 1920s, voluntary migrants to Manchuria, primarily male, were joined by refugees, many of them women and children, forced to search for a safer home, as well as contract laborers ("coolies"), working under slave-like conditions on estates and in mines $^{18}$.

The Great Migration to northeastern China was equal to simultaneous mass migrations in other parts of the world. From 1891 to 1942, 25.4 million people migrated from northern China to Manchuria, 16.7 million returned, leaving a net transfer of 8.7 million. Most of the Han-Chinese settlements emerged along rivers and railroads, which facilitated bringing migrants in and shipping produce out, thereby linking these areas to market exchange. The young men who left their villages in northern China to make their way through Manchuria to the outer edges of settlement initially expected to earn money and return home to their families. Finally, they connected to social networks that channeled them to towns, villages, and farms. Rather than adapting to

\footnotetext{
17 Ibid., 71-84; James Reardon-Anderson, "Land Use and Society in Manchuria and Inner Mongolia during the Qing Dynasty," Environmental History 5, no. 4 (2000): 503-30, https://doi.org/10.2307/3985584.

18 Thomas Gottschang and Diana Lary, Swallows and Settlers: The Great Migration from North China to Manchuria (Ann Arbor, MI: University of Michigan Press, 2000), 38; Thomas R. Gottschang, "Economic Change, Disasters, and Migration: The Historical Case of Manchuria," Economic Development and Cultural Change 35, no. 3 (1987): 461-90; Kungtu C. Sun, The Economic Development of Manchuria in the First Half of the Twentieth Century (Harvard University Asia Center, 1969), 19-41, https://doi.org/10.2307/j.ctt1tg5hhd; Chao, The Economic Development of Manchuria, 1-21; Reardon-Anderson, Reluctant Pioneers: China's Expansion Northward, 1644-1937, 147-59, 208-9.
} 
the world around them, the new villages became extensions of the old ones, bound together by the values of family and peasant community. Serial migration from south to north enabled social upward mobility, as former laborers and tenants invested their earnings to become landowners and found families ${ }^{19}$.

With the crisis-driven reclamation and cultivation of land by Han-Chinese settlers, soybean fields expanded rapidly from south to north along rivers and railroads. Soybeans were part of the cultural luggage settlers carried with them. Whole beans had been used in East Asia for centuries for foodstuffs in non-fermented (tofu, soy milk, okara, etc.) and fermented forms (soy paste, soy sauce, natto, etc.) ${ }^{20}$. Manchurian peasants usually planted soybeans once within a three- or four-year cycle of crop rotation. They tediously cultivated the plants almost entirely by hand methods: The soil was broken in April, using a single-handled, steel-tipped plough, drawn by a mixed team of oxen, mules or donkeys. The seed was sown and covered by hand, and fertilized, if at all, with a compost of manure and soil. Since the plant matured very slowly and fertilizer was in short supply, the weeds had to be removed manually several times by carefully turning and breaking the ground with a heavy hoe. The beans were harvested in September by pulling the plants up by the roots or cutting them with a sickle before they had fully ripened. After drying, the seeds were separated from the pods using a stone roller, dragged by a mule. Winnowing was done by throwing the mixture of beans and chaff against the wind. Once dried and separated, the beans were ready for household self-consumption or for market sale as a whole or as oil separated from cake through crushing ${ }^{21}$.

According to the Kotoku surveys of the mid-1930s, landed property in Manchuria was highly concentrated, with a gradient running from the more equal south to the more unequal north. On average, the property of the biggest owners was tenfold the property of the others. However, leasing of nearly half of the landed property by the biggest owners alleviated the inequality. With the land rents paid by the tenants, the biggest owners hired twice the amount of labor capacity provided by

\footnotetext{
${ }^{19}$ Reardon-Anderson, Reluctant Pioneers: China's Expansion Northward, 1644-1937, 127-46.

${ }^{20}$ Christine M. Du Bois and Sidney Mintz, "Soy," in Encyclopedia of Food and Culture: Volume 3, ed. Solomon H. Katz (New York: Scribner, 2000).

${ }^{21}$ Reardon-Anderson, Reluctant Pioneers: China's Expansion Northward, 1644-1937, 179-88; Imperial Maritime Customs (China), The Soya Bean of Manchuria (Shanghai: Inspector General of Customs, 1911), 4-5.
} 
their own family members. The wage laborers came from the households of landless workers, which made up 30 percent of the total households of the villages covered by the surveys. The other owners relied predominantly on family labor, while the tenants ran pure family farms. One striking feature concerns the weight of soybean production: While crop selection showed some differences by household class, the share of the acreage sown with soybeans was similar at one fifth of the cultivated land. Although big landowners had enough revenues to specialize in soybean cash crop production with advanced technology, they did not do so; instead, they used their land the same way as the other landowners ${ }^{22}$.

Reardon-Anderson's explanation for the uniformity of land use draws on social and cultural aspects: Chinese farmers, regardless of farm size, were reluctant to change due to their risk-averse habitus, reflecting the values of family and peasant community. They all "used simple, traditional technologies, favored small organizations with small financing, and moved their investments among various business activities based on a preference for short-term profits and low risks" ${ }^{23}$. However, the uniformity of land use also involves politico-economic interdependencies: Since soybean production relied on simple technology, large farmers did not enjoy advantages due to economies of scale. The basic equipment, comprising two draft animals and a plough, was commonly available on medium and even on small farms as well. Indeed, the reverse was the case: medium and small family farms with rather intrinsically motivated laborers enjoyed a cost advantage over large farms, where rather extrinsically motivated wage laborers had to be monitored to ensure the quantity and quality of work (e.g. weeding the soybean fields as carefully as possible $)^{24}$. This was probably the reason why the pure family farms of tenants gained more yield per labor unit than the mixed family-wage work farms of most landowners. Only the big owners more than compensated their disadvantage obviously not through more productive technology, but through more exploitive labor relations: on the one hand, they had considerable leverage over wage laborers due to

\footnotetext{
22 Reardon-Anderson, Reluctant Pioneers: China's Expansion Northward, 1644-1937, 220-33.

23 lbid., 196.

24 See: Douglas W. Allen and Dean Lueck, "Agricultural Contracts," in Handbook of New Institutional Economics, ed. Claude Menard and Mary M. Shirley (Berlin, Heidelberg: Springer-Verlag Berlin Heidelberg, 2008), 479-80.
} 
the enormous number of landless people; on the other hand, landless households sent their most efficient members - usually young men - to wage work on large holdings in order to maximize earnings ${ }^{25}$.

\section{INTERNAL SOY EXPANSION IN THE USA, 1930s-1970s}

The USA emerged as a soy powerhouse from the 1930s onwards and dominated the world market until the 1970s, with Western Europe and Japan as its main customers ${ }^{26}$. After take-off in the 1930s and acceleration in the 1940s, soy cropping expanded strongly from the 1950s to the 1970s and, after stagnation in the farm debt crisis of the 1980s, continued to grow again since the 1990s (Figure 02). For the purpose of comparison, this article focuses on the US soy expansion in the period of world market dominance until 1973, while disregarding the developments in the following decades. The 313-fold growth of production from 1924 to 1973 resulted mainly from the 36 -fold enlargement of cultivated land devoted to soybeans, but also from the 8.7-fold rise in yields per acre. Though total farmland decreased, soybeans increasingly displaced grains such as oats, barley, and wheat in the Midwest and cotton in the South. Land productivity improved through application of technologies such as high-yielding varieties, agrochemicals and moto-mechanization. Thus, the US soy expansion predominantly moved ahead along the internal commodity frontier ${ }^{27}$.

The "American frontier," expanding from east to west, had already been closed as soybeans entered US agriculture. From the mid-nineteenth century onwards, the Corn Belt, covering the states of Ohio, Indiana, Illinois, Iowa, and Missouri, had emerged as a center of commercial corn-livestock production. The region offered a mid-continental climate with cold winters and warm summers as well as former grassland soils rich in nutrients ${ }^{28}$. However, declining corn yields after the turn of the century, due to overexploitation, and depressed commodity prices in the interwar period, due to overproduction, plunged the region's farming community into a

\footnotetext{
25 Reardon-Anderson, Reluctant Pioneers: China's Expansion Northward, 1644-1937, 226-29.

26 Matthew Roth, Magic Bean: The Rise of Soy in America (Lawrence, Kansas: University Press of Kansas, 2018); Prodöhl, "Versatile and Cheap: A Global History of Soy in the First Half of the Twentieth Century."

27 Data source: US Department of Agriculture, "National Agricultural Statistics Service," 2019, http://www.nass.usda.gov.

28 David J. Connor, Robert S. Loomis, and Kenneth G. Cassman, Crop Ecology: Productivity and Management in Agricultural Systems, 2nd ed. (Cambridge: Cambridge University Press, 2011), 459-70.
} 
fundamental crisis. Approaches to solving the ecological and economic crisis resulted in two crop innovations that became pillars of Corn Belt agriculture from the 1930s onwards: one solution was the introduction of high-yielding varieties of hybrid corn as part of the technological package of American-style capital-intensive farming. The other solution was the introduction of a neophyte deriving from Asian-style laborintensive farming - the soy plant ${ }^{29}$.

Figure 02. Soy expansion in the USA, 1924-2015.

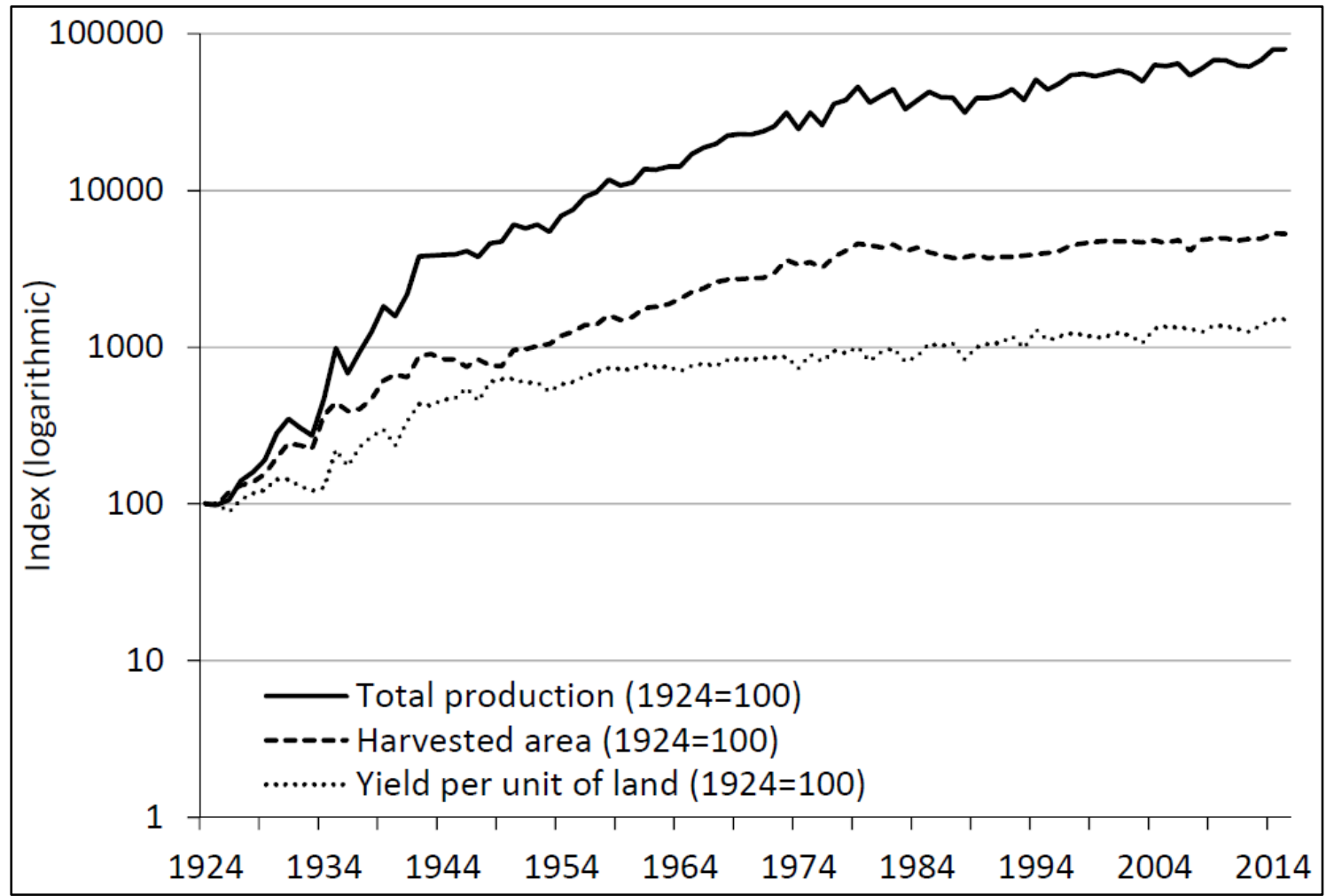

Data source: see ref. 27

While previously known to natural scientists, religious minorities, and Asian immigrants only, the exotic plant caught the attention of the US Department of Agriculture (USDA) at the turn of the century. The official closing of the US frontier in 1890 had reoriented agricultural research and development from the areal extension of European-style farming, based on nutrient mining on former prairie grasslands, to more intensive and sustainable land uses. Since the turn of the century, the USDA commissioned a series of expeditions to East Asia (e.g. the Dorsett-Morse expedition from 1929 to 1931) in order to search for soy varieties adapted to the climate, soil, and

29 John C Hudson, Making the Corn Belt: A Geographical History of Middle-Western Agriculture (Bloomington, Indiana: Indiana University Press, 1994), 151-72. 
latitude of North America. Among several thousands of collected soy samples, 41 were selected as US cultivars and crossbred to be adapted to particular conditions. By the 1920s, farmers in the Mississippi Valley and Corn Belt had begun to plant soybeans first for hay, but then also for beans processed by emerging oilseed mills. Henry Ford's obsession with the soybean as a raw material for the automobile industry caused sensation in the mass media, but never proceeded far beyond experimental stage. Despite these administrative and commercial efforts, soy farming and processing remained a niche business ${ }^{30}$.

The transition from niche to mainstream took off only in the mid-1930s, driven by both institutional and technological developments. At the institutional level, the federal state began to regulate soy-based commodity chains in several steps: first, the New Deal administration managed the economic and ecological crisis through setting-aside corn and other price-depressed crops as well as introducing soilenriching plants on eroded fields, thereby opening a window of opportunity for the soybean as an alternative. Second, the wartime government successfully encouraged US farmers to grow price-subsidized oilseeds such as soybeans for food purposes in order to save scarce tropical oils for military use. Third, the favorable commodity prices due to export-oriented trade policies after the war fueled soybean surpluses, which were channeled, for one, as oil to the manufacturing of margarine and other foodstuffs and, for another, as cake to the livestock-feeding complex, both at home and abroad, in Western Europe and Japan ${ }^{31}$.

At the technological level, the transition to capital-intensive farming based on fossil fuels accelerated the integration of soybeans into the cropping system of the Midwest and South in multiple ways: first, due to the replacement of draft animals by tractors, acreage formerly used for feed crops became available for cash crops such as soybeans. Second, since combines for corn harvesting and threshing were also appropriate for soybeans, no special machinery had to be purchased in the Corn Belt.

\footnotetext{
30 Du Bois, The Story of Soy, 53-69.

31 Ines Prodöhl, "From Dinner to Dynamite: Fats and Oils in Wartime America," Global Food History 2, no. 1 (2016): 31-50, https://doi.org/10.1080/20549547.2016.1138366; Raj Patel, Stuffed and Starved: Markets, Power and the Hidden Battle for the World Food System (London: Portobello Books, 2008), 169-73; Christine M. Du Bois, "Social Context and Diet: Changing Soy Production and Consumption in the United States," in The World of Soy, ed. Christine M. Du Bois, Chee-Beng Tan, and Sidney Mintz (illinois: University of Illinois Press, 2008), 20614.
} 
In the Mississippi Delta, soy, in combination with corn, rather drove the adoption of new technologies, since most cotton farms had yet to be motorized with aid of statesubsidized credits. Third, crop rotation of nitrogen-mining corn and nitrogen-fixing soybeans accrued ecological and economic advantages by saving commercial fertilizer. Within a few decades, the soy frontier had expanded deeply into the Midwest and South, thus shaping the agrarian landscape. Already in the mid-1950s, the Corn Belt was officially termed "Corn-Soy Belt" 32 .

As technological change progressed in the Corn Belt from the mid-1930s onwards, soybean cultivation required less manual labor and more farm machinery, as depicted by the instructional film Soybeans for Farm and Industry from about 1940. It demonstrates the application of a multitude of tractor-drawn machines: soil preparation with the disc harrow, fertilizing with the manure distributor, sowing with the seed drill, weeding with the rotary hoe, weeder, and cultivator, cutting for hay with the mower, harvesting and threshing for beans with the combine, and so on. The only human being who appears on the field is the tractor driver ${ }^{33}$. This notion of a fully-mechanized one-man farm was exaggerated, since neither family labor nor hired labor disappeared: in Iowa, a typical Corn Belt state, the average number of hired laborers per family farm even rose from 1.2 in 1950 to 1.4 in 1964, reflecting farm growth from 68 to 89 hectares $^{34}$. However, the film did accurately forecast the vanishing point of the already ongoing transition from labor-intensive to capitalintensive farming. With the advent of large-scale machinery such as self-propelled combines, soy farming, along with corn cropping, faced economies of scale. Iowa in the mid-1960s provides a telling case: although the percentage of the acreage covered by soybeans was slightly below or above one fifth for all classes (except for the smallest farms), the percentage of farms planting soybeans positively correlated with farm size. Conversely, the number of combines per 1,000 acres cropland negatively correlated with farm size, thus indicating scale effects to the advantage of larger

\footnotetext{
32 Joseph Leslie Anderson, Industrializing the Corn Belt: Agriculture, Technology, and Environment, 1945-1972 (DeKalb, Illinois: Northern Illinois University Press, 2009), 152-67; Jeannie M. Whayne, A New Plantation South: Land, Labor, and Federal Favor in Twentieth-Century Arkansas (Charlottesville, VA: University Press of Virginia, 1996), 157-75; Ladd Haystead and Gilbert C. Fite, The Agricultural Regions of the United States (London: Methuen \& Co., 1955), 140.

${ }^{33}$ AC 741 Wisconsin Historical Society, International Harvester Company Film Collection, "Soybeans for Farm and Industry," accessed October 1 , 2019, http://archive.org/details/0914_Soybeans_for_Farm_and_Industry_00_21_44_29.

34 US Bureau of the Census, "Census of Agriculture 1964 - lowa" (Washington, DC: US Government Printing Office, 1967), 7, 11.
} 
farms (Figure 03$)^{35}$. Saving labor and money were the farming families' main motives for purchasing or renting machines. Their success in doing so required some creativity: "But the willingness of farmers to experiment, on the faith that sooner or later the new machines would help them harvest with greater financial and labor savings, was the most influential factor in their acceptance of the combine" ${ }^{36}$.

Figure 03. Soy cropping and mechanization by farm size in lowa, 1964.

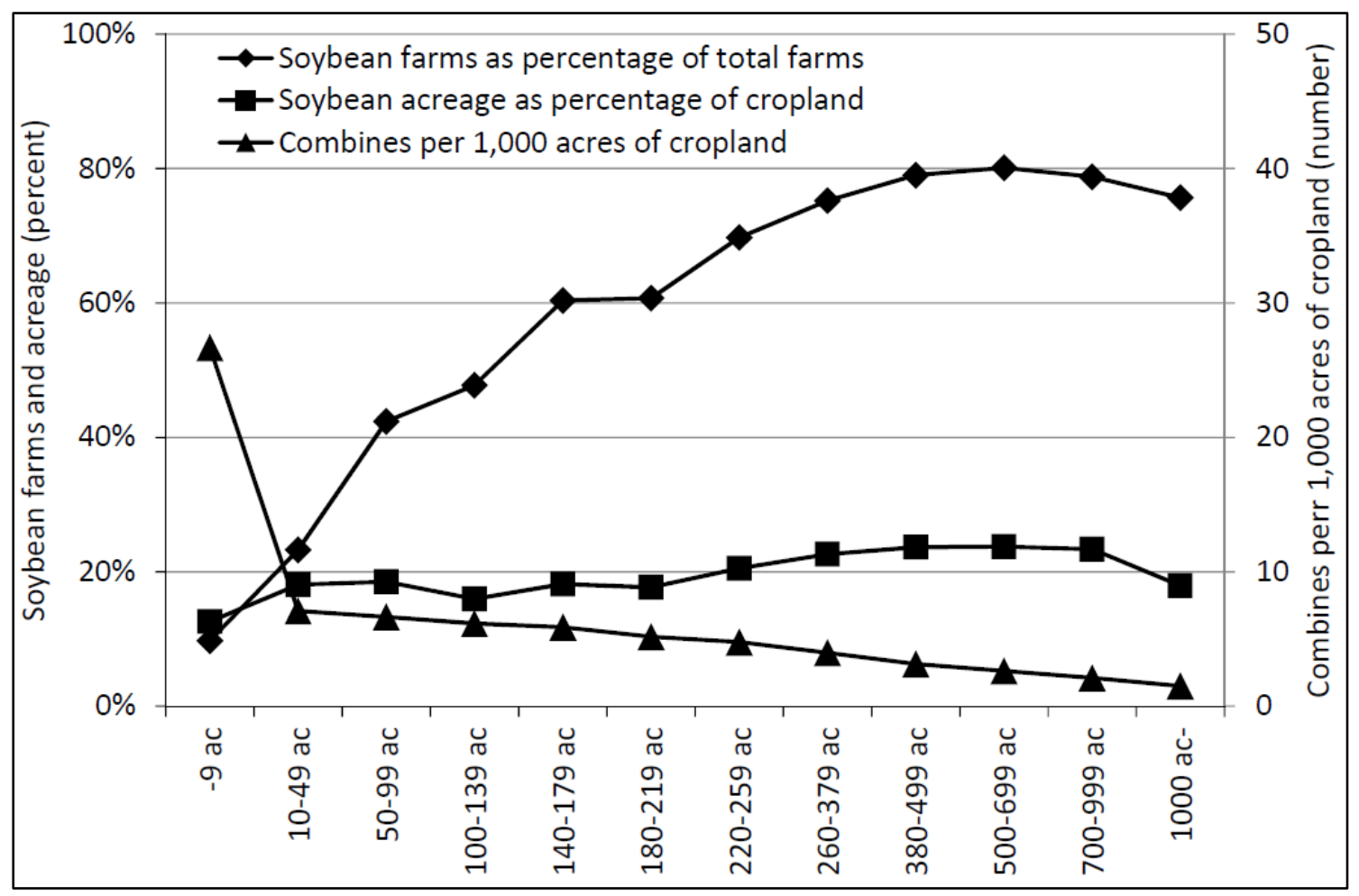

Data source: see ref. 35

The mechanization of Corn Belt farms closely interacted with the social relations of farming families. On the one hand, the decision to invest in farm equipment arose from not only operational calculations, but also reflected priorities of family life. Apart from the families' general motive of reducing bodily strain, farmwomen were especially thankful for machines that reduced the need to engage seasonal workers. For instance, corn pickers got their wages by the bushel and received room and board for the duration of the harvest. Unlike permanent workers who did other farm-work in case of unfavorable weather, corn pickers waited inside the house for conditions to improve - and had to be served by the farmwomen. On the other hand, farm mechanization changed the gendered division of labor within the

\footnotetext{
35 Data source: Ibid., 74-87.

${ }^{36}$ Anderson, Industrializing the Corn Belt: Agriculture, Technology, and Environment, 1945-1972, 158.
} 
family. Contrary to the women's multiple roles in agricultural production, the adoption of the full-mechanized farm model, framing the male farmer as "master" of the machinery, increasingly relegated the farmer's wife to household work. Thereby, the separation of farm enterprise and household unfolded, while working and living spaces still intersected on the family farms ${ }^{37}$.

While the above-mentioned film highlighted mechanical innovations, the US soy expansion also relied on agrochemicals, i.e. commercial fertilizers and pesticides. Initially, agricultural scientists, extension professionals, and farm journalists discouraged farmers from fertilizing the nitrogen-fixing soybean crop, since the benefits were unlikely to outweigh the costs. However, Corn Belt farmers challenged received wisdom by applying commercial fertilizers to soybeans in the same way as they did to corn. While this trial-and-error method proved to be more or less effective, the application of pesticides, especially herbicides, to soy fields achieved far-reaching effects. Herbicides promised an effective response to weeds as a severe challenge during the soybean's growth cycle. In a sense, the postwar battle against weeds continued the battle against the axis powers during the war: the herbicide 2,4D, which the University of Chicago had experimented with as a weapon for biological warfare, was an effective growth regulator, causing the plant to literally grow itself to $\operatorname{death}^{38}$.

From the 1950s onwards, farmers widely adopted 2,4-D as a simple and cheap tool for eliminating weeds in the Corn Belt and elsewhere. Exciting success stories, distributed among the farming community, overshadowed the experts' advice to balance chemical and mechanical practices. In fact, farmers' excessive application of 2,4-D effectively eliminated broadleaf weeds, but simultaneously created selection pressure in favor of weeds tolerant of this herbicide, thereby aggravating rather than alleviating the problem. Corn Belt farmers consequently saw themselves forced to apply ever more 2,4-D as well as alternative herbicides developed by the chemical industry, thus rendering weed control more complex and expensive. By the 1970s, corn and soy farmers faced the vicious cycle of intended actions to manage the

37 Jane Adams, The Transformation of Rural Life: Southern Illinois, 1890-1990 (Chapel Hill: University of North Carolina Press, 1994), 243-53; Anderson, Industrializing the Corn Belt: Agriculture, Technology, and Environment, 1945-1972, 169-71.

${ }^{38}$ Anderson, Industrializing the Corn Belt: Agriculture, Technology, and Environment, 1945-1972, 33-50, 62-63. 
agroecosystem and unintended reactions. However, they embraced herbicides and experimented from day to day to shape their use, since they tried to avoid the labor effort and expenses associated with mechanical cultivation ${ }^{39}$.

\section{FLEXIBLE SOY EXPANSION IN BRAZIL, 1970s-2010S}

Figure 04. Soy expansion in Brazil, 1961-2014.

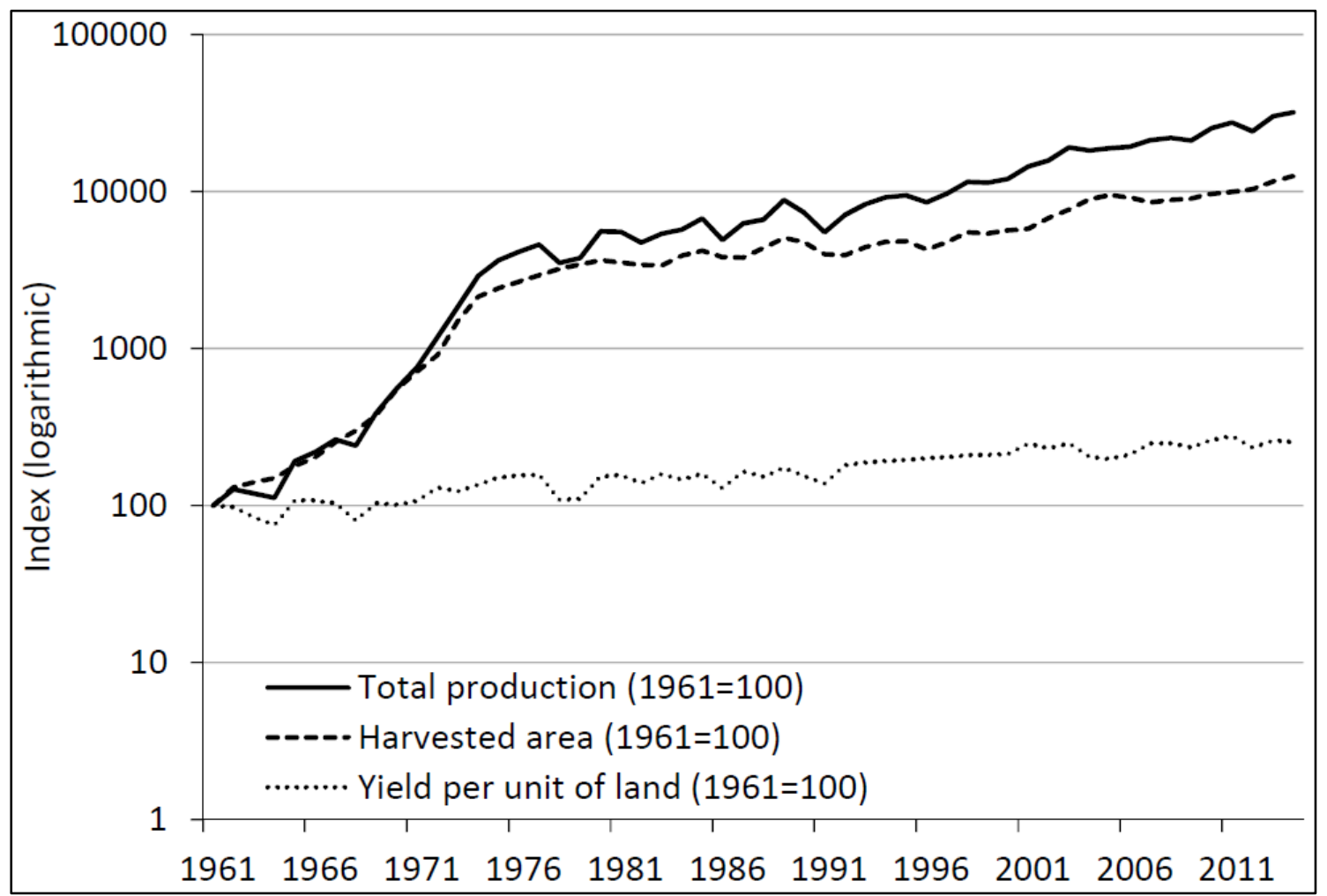

Data source: see ref. 41

US dominance in the world market for soybeans increasingly came under pressure in the 1970s from the countries of South America's "soylandia.". Among these countries, Brazil stands out as the leading producer and exporter and, thus, provides a telling example for soy expansions in the Southern Cone ${ }^{40}$. The Brazilian soy expansion unfolded in two bursts of growth: the first one from the 1960s to the 1970s, driven by state-led development and an international supply crisis of US soybeans, and the second one from the 1990s onwards, reflecting agro-neoliberalism as well as

\footnotetext{
39 See: ibid., 33-50.

${ }^{40}$ Klein and Luna, Feeding the World: Brazil's Transformation into a Modern Agricultural Economy; loris, Agribusiness and the Neoliberal Food System in Brazil: Frontiers and Fissures of Agro-Neoliberalism; Mariano Turzi, The Political Economy of Agricultural Booms (Cham: Springer International Publishing, 2017), https://doi.org/10.1007/978-3-319-45946-2; Pablo Lapegna, Soybeans and Power (Oxford University Press, 2016), https://doi.org/10.1093/acprof:oso/9780190215132.001.0001.
} 
European and Chinese demand (Figure 04). The expansion of production by the factor 320 from 1961 to 2014 mainly resulted from the 126-fold extension of the soybean area, for the most part through conversion of near-natural savannah grasslands and forests in the Center-West Region. Meanwhile, the 2.5-fold rise in yields per land unit, accomplished through more productive technology adapted to (sub-)tropical conditions, played a minor, though increasingly important role. The Brazilian soy expansion combined movements along the external frontier, such as in the Manchurian case, as well as along the internal frontier, such as in the US case. Thus, it can be regarded as a case of flexible - i.e., both external and internal - shift of the commodity frontier ${ }^{41}$.

The soybean, which had been adopted as a crop in Rio Grande do Sul in the very south of Brazil in the 1920s, did not play a significant role in agriculture before its expansion took off in the 1970s. Initially, soy varieties from the USA and Japan were grown under moderate climate on mixed peasant farms for hay and, from the 1940s onwards, for beans to extract cooking oil and animal feed for the domestic market. In the course of only a few decades, however, soybeans gained (trans-)national importance due to political, economic, and ecological impacts. First, the military dictatorship, established in 1964, implemented a high-modernist program of agroindustrial development to fix several problems at once: creating jobs for the rural poor who had been disadvantaged by urban-centered Import Substitution Industrialization; securing cheap food for the urban poor who had moved to the cities from the countryside; counterbalancing the country's negative trade balance through raising agricultural exports; and colonizing "empty" landscapes in the vast territory of the country for geopolitical reasons ${ }^{42}$. Second, a supply crisis of North American soybeans due to years of bad harvests, massive purchases by the USSR, and a subsequent US trade embargo stacked against Japan and Europe in 1973 culminated with shortages of soy's key substitutes as animal feed, Peruvian fishmeal and West

\footnotetext{
41 Data source: "Faostat."

42 Paulo Alfredo Schönardie, Bäuerliche Landwirtschaft Im Süden Brasiliens: Historische, Theoretische Und Empirische Studie Zu Ernährungssouveränität, Modernisierung, Wiederbelebung Und Staatsfunktion (München: Oekom Verlag, 2013), 236-47; Patel, Stuffed and Starved: Markets, Power and the Hidden Battle for the World Food System, 173-81; Du Bois, The Story of Soy, 116-33; Ivan Sergio Freire de Sowa and Lawrence Busch, "Networks and Agricultural Development: The Case of Soybean Production and Consumption in Brazil," Rural Sociology 63, no. 3 (1998): 349-71, https://doi.org/10.1111/ruso.1998.63.3.349; Turzi, The Political Economy of Agricultural Booms, 83-85.
} 
African peanuts due to an El Niño Southern Oscillation. The resulting spike of soy prices in the 1970s not only offered incentives to domestic commercial farmers for expanding soy cropping, but also to Japanese and European capital for investing in Brazil's transport and processing facilities to reduce dependency on US exports ${ }^{43}$. Third, the Brazilian soy expansion further accelerated in the 1990s because of the Mad Cow Disease in the UK and other parts of Europe as well as post-reform China's growing appetite for meat, as both developments raised demand for soy cake as animal feed. Consequently, China joined international investors in Brazil's growing soy complex ${ }^{44}$. Fourth, Brazil's hyperinflation in the 1980s, accompanied by the resignation of the military dictatorship, permitted foreign multinationals such as Archer Daniels Midland, Bunge, and Cargill to buy large parts of the state-sponsored soy industry. The republican government supported (trans-)national agribusinesses through trade liberalization in the frameworks of the Mercosur agreement and the World Trade Organization. Vested interests of multinational corporations were thereby represented as those of the "whole nation"45.

As these driving forced gained momentum, the Brazilian soy frontier crossed natural boundaries between the moderate south and the savannah region (cerrado) in the tropical north, moving from the state of Rio Grande do Sul though Paraná, Mato Grosso do Sul, and Goiás to Mato Grosso. According to the strategic articulation of public and private agendas, domestic and foreign capital invested in the mobilization of productive resources: newly constructed highway connections to ports cross-cut the Amazonian rainforest in south-north direction; commercial farms run by white immigrants from southern states converted vast tracts of "virgin lands;" the public research agency Embrapa in cooperation with US universities developed site-specific productive technologies such as soybean varieties adapted to acid soils, tropical climate, and smaller latitude (e.g., FT Cristalina) ${ }^{46}$. Since unused or only extensively

\footnotetext{
43 Patel, Stuffed and Starved: Markets, Power and the Hidden Battle for the World Food System, 181-87; Du Bois, The Story of Soy, $166-133$.

44 Du Bois, The Story of Soy, 116-33.

45 Patel, Stuffed and Starved: Markets, Power and the Hidden Battle for the World Food System, 181-87; Bill Vorley, Food, Inc.: Corporate Concentration from Farm to Consumer (London: UK Food Group, 2003), 44.

${ }^{46}$ Claiton Márcio da SILVA, "Entre Fênix e Ceres: A Grande Aceleração e a Fronteira Agrícola No Cerrado," Varia Historia 34, no. 65 (2018): 409_ 44, https://doi.org/10.1590/0104-87752018000200006; Ivan Sergio Freire de Sousa and Rita de Cássia Milagres Teixera Vieira, "Soybeans and Soyfoods in Brazil, with Notes on Argentina: Sketch of an Expanding World Commodity," in The World of Soy, ed. Christine M. Du Bois, Chee-Beng Tan, and Sidney Mintz (illinois: University of Illinois Press, 2008), 181-87; Connor, Loomis, and Cassman, Crop Ecology: Productivity and Management in Agricultural Systems, 476-82.
} 
used land in the savannah and rainforest areas was reclaimed, the expansion of Brazilian soy farming resembled the expansion of European-style farming at the US frontier one century earlier. This pattern of soy expansion corresponded to the farmers' "frontier mentality," much like the mindset of the European settlers in nineteenth-century North America, driven by the obsession to replace wilderness by civilization. Accordingly, values such as conquering nature, securing income, and achieving progress became hegemonic in public discourses on soy farming, as institutionalized by the congressional rural bloc (bancada ruralista) and the businesscontrolled mass media ${ }^{47}$.

The Brazilian soy expansion relied on large-scale machinery both directly, through application of mechanical inputs (e.g. large-scale combines), and indirectly, through devices for applying chemical inputs (e.g. spraying machines or "mosquitos"). The moto-mechanization of Brazilian soy farming involved economies of scale, as revealed by the agricultural census of 2006: both the percentage of farms growing soybeans and the percentage of the acreage covered by soybeans positively correlated with farm size. In short, the bigger the farm, the heavier the soybean's weight. Conversely, the number of combines per 1,000 hectares cropland negatively correlated with size on farms larger than 100 hectares. Medium owners probably used their combines not only on their own 20 to 100 hectares of farmland, but also rented them to smaller farms lacking such large-scale devices (Figure 05) ${ }^{48}$. This economic driver was reinforced by government policies, directing green-revolution technologies towards large-scale farms ${ }^{49}$. In response to shifting economies of scale, businessmen created 'network firms' (pools de siembra) that pooled financial capital from different sources, leased huge tracts of land cultivated by subcontractors, and split returns among investors. This capitalist mode of "farming without farmers", fundamentally depending on factor and product markets, was disconnected from

\footnotetext{
47 Turzi, The Political Economy of Agricultural Booms, 85-91.

48 Data source: IBGE, "Censo Agropecuário 2006: Brasil, Grandes Regiões e Unidades Da Federação" (Rio de Janeiro, 2006), https://biblioteca.ibge.gov.br/visualizacao/periodicos/51/agro_2006.pdf Tab. 1.2.14, 1.2.23, 1.6.73.

49 Turzi, The Political Economy of Agricultural Booms, 84.
} 
social ties of family and neighborhood as well as from metabolic cycles of regional ecosystems ${ }^{50}$.

Figure 05. Soy cropping and mechanization by farm size in Brazil, 2006.

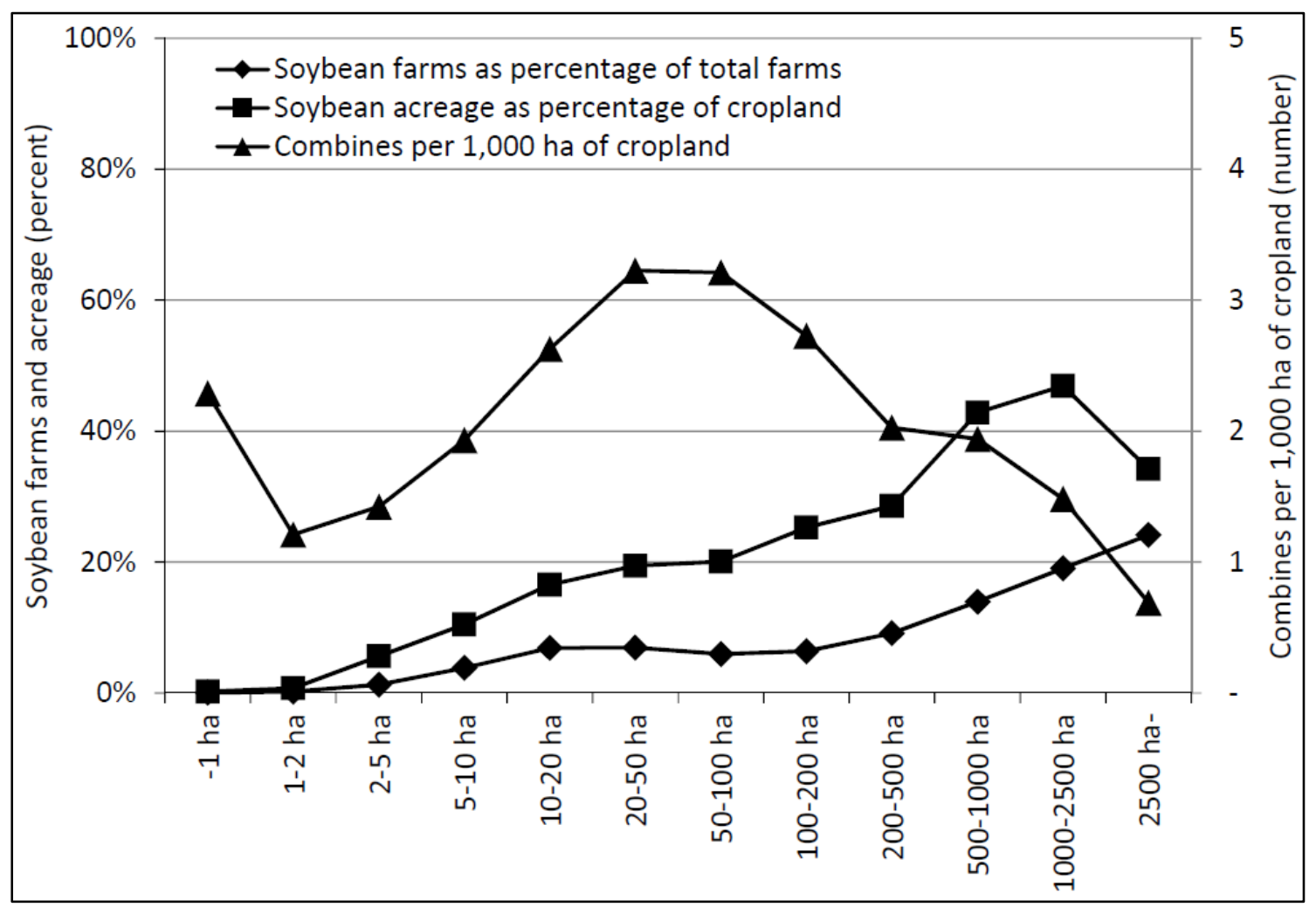

Data source: see ref. 48

Application of mechanical and chemical technologies, most notably pesticides, on Brazilian soy fields went hand in hand. The soybean's general vulnerability to weeds during its early growth phase caused special problems in the savannah region: monocultures and soy-grain rotations as well as the tropical climate opened up a niche for weeds. Therefore, farmers applied more and stronger herbicides to the fields by sprayers and crop dusters than elsewhere. Since many herbicides kill not only weeds but also crops, farmers found proper application quite difficult - hence their unreserved welcoming of the herbicide-tolerant soy variety introduced by the US company Monsanto in 1996. Through genetic modification (GM), Monsanto's Roundup-Ready soy seeds became resistant to glyphosate, marketed under the label Roundup by the same company. Glyphosate is an efficient plant killer that soon breaks down into quite harmless substances and, hence, is less toxic to animals and humans

${ }^{50}$ Matilda Baraibar Norberg, The Political Economy of Agrarian Change in Latin America (Cham: Palgrave Macmillan, 2019), 6-21. 
than many other herbicides. Applied in combination with glyphosate-tolerant seeds, glyphosate thus simplified and cheapened soy cultivation. Since the Brazilian government legalized GM soybeans only in 2005, transgenic seeds illegally crossed borders from Argentina, where they already had been approved in 1996, and other neighboring countries. By 2014, 93 percent of the soybeans planted in Brazil were glyphosate-tolerant ${ }^{51}$.

Instead of slowing down the vicious cycle of high-tech farming, the application of transgenic soybeans accelerated the "metabolic rift" between human actions and non-human reactions. Some years after their introduction, what worried farmers most was the appearance of glyphosate-tolerant weeds on their fields. "Superweeds" emerged through genetic and epigenetic mutations due to strong selection pressure for resistance among wild plants from over-application of glyphosate. Since they resisted normal doses of glyphosate, farmers tried to combat them through application of more and stronger herbicides, thereby making soy cultivation more troublesome and costly. The agrochemical industry soon reacted to this demand by supplying mixtures of glyphosate and 2,4-D, for eliminating conventional weeds and "superweeds," respectively. Overall, the application of herbicides, especially glyphosate, has skyrocketed since the introduction of GM soybeans ${ }^{52}$.

Brazil's soy expansion was not only a burden on nature, with regard to degraded biodiversity, soil health, and water purity, but hit rural society as well. The market-driven and state-supported expansion of commercial soy farms, often run by white farmers of European or US descent, threatened peasant communities, including indigenous people, by illegal and legal means. Most importantly, the ongoing struggle for land disrupted rural livelihoods. Where landed property rights were insecure, peasant families were displaced through brute violence, including murder, by large landowners and their henchmen. For instance, 390 Indians were killed in Mato Grosso do Sul between 2003 and 2014. Where land titles prevailed, rising land prices led smallholders to sell their landed property in order to make a living elsewhere. The

${ }^{51}$ Du Bois, The Story of Soy, 161; Christine M. Du Bois and Ivan Sergio Freire de Sousa, "Genetically Engineered Soy," in The World of Soy, ed. Christine M. Du Bois, Chee-Beng Tan, and Sidney Mintz (illinois: University of Illinois Press, 2008), 74-98.

52 Lapegna, Soybeans and Power, 37-45; Du Bois, The Story of Soy, 163-66. 
state promoted the marketization of land through regulatory measures. For instance, in a recent Ecological Economic Zoning Plan for the highway BR-163, lands occupied by peasant and indigenous landholders were designated for soy farming and extractive industries. Land sales also resulted from the collateral damages of soy expansion. Small landholders enclosed by expanding soy farms saw themselves cut off from their personal networks, thus abandoning their farms. Besides the loss of social capital, soy expansion also undermined the peasantry's natural resource base. Most disastrous were agrochemical drifts due to large-scale spraying of herbicides on fields planted with GM soybeans, harming neighboring people as well as their livestock and conventional crops. As a consequence of illegal and legal land transfers, concentration of farm size and, thus, income inequality in soy production has proceeded faster in the last decades and is on a higher level today than in most other branches of agriculture $^{53}$.

The legal and illegal expansion of soy farms led to large-scale displacement of the peasant population. In 2002, five million landless families were registered in Brazil. Many of the displaced people resorted to rural-urban migration to make a living, either through formal occupation in the manufacturing and service sectors or through informal work in the crowded slums of megacities. Some flocked to the selforganized communities of the Landless Rural Workers' Movement (Movimento dos Trabalhadores Sem Terra, MST), which was reclaiming large tracts of land lacking a "social function" according to the 1988 constitution. Those who stayed in the near countryside, often lacking a roof over their heads, hired themselves out as wageworkers in the labor-intensive branches of export-oriented agriculture such as sugarcane production and cattle ranching. They often were roped into the vicious cycle of unfree labor (trabalho escravo), forcing them to amortize their (mostly unjustified) debts through work under slave-like conditions in peripheral regions.

\footnotetext{
53 Lapegna, Soybeans and Power, 84-114; Turzi, The Political Economy of Agricultural Booms, 91-97; Andrew Ofstehage, "Farming Is Easy, Becoming Brazilian Is Hard: North American Soy Farmers' Social Values of Production, Work and Land in Soylandia," The Journal of Peasant Studies 43, no. 2 (2016): 442-60, https://doi.org/10.1080/03066150.2014.998651; Brenda Baletti, "Ordenamento Territorial: Neo-Developmentalism and the Struggle for Territory in the Lower Brazilian Amazon," Journal of Peasant Studies 39, no. 2 (2012): 573-98, https://doi.org/10.1080/03066150.2012.664139; Rachael D. Garrett and Lisa L. Rausch, "Green for Gold: Social and Ecological Tradeoffs Influencing the Sustainability of the Brazilian Soy Industry," The Journal of Peasant Studies 43, no. 2 (2016): 472-73, https://doi.org/10.1080/03066150.2015.1010077.
} 
Between 2003 and 2012, 63,417 cases of enslaved rural laborers and 2,569 landowners accused of serious labor code violations were officially registered ${ }^{54}$.

The most important impact of the Brazilian soy expansion on labor relations was quantitative, i.e. the reduction of on-farm work through adoption of the laborsaving technological package of agro-industrial farming. Between 1985 and 2004, a period in which production nearly tripled, employment on soy farms fell by 80 percent, from 1.7 million to 335,000 workers. Most employment opportunities in the soy complex rise off farm, in related agribusiness such as transportation, processing and services. However, job-hunting residents are often unable to acquire the new positions created by agribusiness due to lack of adequate skills; immigrants from southern Brazil often take these jobs, leading to conflict with the residing populations and outmigration ${ }^{55}$.

Besides the quantities of job losses, soy expansion had also qualitative impacts on working conditions. The labor force in agricultural frontier regions such as Mato Grosso segmented into a majority of underpaid and unskilled helpers for laying out fields on the one hand and a minority of well-paid and skilled crafters for operating the mechanical and chemical facilities on the other hand. While many employees in the upper segment only work at the farm and live with their families in nearby cities with good infrastructure, workers in the lower segment regularly face dire conditions such as hard work, low wages, bad food, dirty dwellings, or social isolation. Wages amount to only 2.6 percent of total costs of soy production in Brazil, compared to 5.0 percent in the USA. However, there are relatively few opportunities for unfree labor in soy farming compared to sugarcane production or cattle ranching. This is not only due to the labor-extensive nature of agro-industrial farming, but also to regulatory

\footnotetext{
54 Patel, Stuffed and Starved: Markets, Power and the Hidden Battle for the World Food System, 204-12; Lisa Carstensen, "Modern Slave Labor' in Brazil at the Intersection of Production, Migration and Resistance Networks," in On Coerced Labor: Work and Compulsion after Chattel Slavery, ed. Marcel M. van der Linden and Magaly Rodríguez García (BRILL, 2016), 267-90, https://doi.org/10.1163/9789004316386_013; Patricia Trindade Maranho Costa and International Labour Organisation (ILO)), Fighting Forced Labour: The Example of Brazil (Geneva: International Labour Office, 2009); Julia Harnoncourt, Unfreie Arbeit: Trabalho Escravo in Der Brasilianischen Landwirtschaft (Wien: Promedia Verlagsges, 2018), 48-87; Wilder Robles and Henry Veltmeyer, The Politics of Agrarian Reform in Brazil: The Landless Rural Workers Movement (Social Movements and Transformation) (New York, NY: Palgrave Macmillan, 2015), 189-95; Daniel M. Cáceres, "Accumulation by Dispossession and Socio-Environmental Conflicts Caused by the Expansion of Agribusiness in Argentina," Journal of Agrarian Change 15, no. 1 (2015): 116-47, https://doi.org/10.1111/joac.12057.

55 Mamerto Pérez, Timothy A. Wise, and Sergio Schlesinger, "The Promise and the Perils of Agricultural Trade Liberalization: Lessons from Latin America," 2008, 12; Garrett and Rausch, "Green for Gold: Social and Ecological Tradeoffs Influencing the Sustainability of the Brazilian Soy Industry," 475.
} 
measures such as the "dirty list of slave labor," published by the President's Secretary of Human Rights. Employers included on this list are barred from accessing public financing such as subsidized rural credit, on which the soy industry heavily depends. In 2014, only 10 out of 583 of the listed farms produced soybeans. Thus, soy expansion brings about unfree labor rather indirectly, through substituting technology for labor, than directly, through exploiting enslaved workers ${ }^{56}$.

In contrast to the Manchurian and US cases, the Brazilian soy expansion provoked massive counter-movements, similar to the resistance to the agroindustrial model of farming in other countries of the Southern Cone. Besides the environmental issue of deforestation in the Amazon basin, the social issue of access to land has been in the center of the public debate on the soy boom. Though the distribution of land in Brazil has been concentrated since colonial times, recent land policies have failed to retard the cycle of concentration. Despite the 1988 constitution, which enabled the state to redistribute land lacking a "social function," the national governments of the 1990s either ignored the land issue or limited agrarian settlements to a low level. Simultaneously, a series of land conflicts led to the formation of the MST, the largest social movement in Latin America. Through land occupation, the MST resettled landless peasants on active or fallow latifundias, gaining public visibility and pushing land reform onto the political agenda. The MST advocates cooperative forms of work and decision-making to improve the sustainability of peasant communities and their environment. In the wake of the MST's rise, the Cardoso administration refocused the land issue. It authorized the MST to do a social, non-state, bottom-up, direct land reform, which was politically less risky than a government-led agrarian reform against the interests of powerful landowners. The MST was an integral part of the social movements' coalition that brought Lula, the candidate of the Workers' Party (PT), to presidency in 2003. Thus, the MST's land reform was expected to proceed by both its supporters and opponents. However, under the PT governments, the land issue received the coup de grâce by the fracturing of the landless movement. Despite initial

\footnotetext{
56 Patel, Stuffed and Starved: Markets, Power and the Hidden Battle for the World Food System, 188-94; Costa and International Labour Organisation (ILO)), Fighting Forced Labour: The Example of Brazil; Carstensen, "Modern Slave Labor' in Brazil at the Intersection of Production, Migration and Resistance Networks"; Turzi, The Political Economy of Agricultural Booms, 96; Garrett and Rausch, "Green for Gold: Social and Ecological Tradeoffs Influencing the Sustainability of the Brazilian Soy Industry," 475.
} 
promises, Lula refused expropriation for the purpose of land reform; accordingly, his plan to settle one million families was cut in half. The number of actually settled families declined year by year, hitting the bottom under the Rousseff's presidency. In 2012, the founder and coordinator of the MST wearily stated that the PT government "had abandoned agrarian reform" as it "could not even solve the social problem of 150,000 families encamped, some for more than five years, along Brazilian roads" ${ }^{257}$.

How can the downturn of land reform, thought to be a protective institution, be explained? In addition to divisions within the MST due to conflicts over community work and life, the state-movement relations were anything but favourable to check the action of the market and respond to the lived experience of marketization. First, the PT's "pro-poor" social programs eroded the MST's social base, since they distracted the working class from the struggle for agrarian reform. Increased social expenditures reduced support for land occupations. Co-optation of labour leaders isolated the MST from its urban ties, thereby fracturing the movement's representation spectrum and hindering their mobilizing capacity. Overall, the MST's dependence on the PT did not serve it well. Second, the federal government authority for settlement, the National Institute for Colonization and Agrarian Reform (INCRA), only reluctantly settled peasants and failed to adequately provide post-settlement programs. Therefore, the newly settled peasants suffered from lack of access to educational, financial, technological, and marketing resources. Though the MST challenged the state to confront this precarious situation, the established programs were incoherent, underfunded, and administrated by urban-based development experts without involvement in rural communities. Moreover, INCRA was accused of corruption with regard to land-grabbing issues. INCRA's doubtful role undermined not only the land reform, but also the MST's position. Third, the MST's orientation towards food sovereignty met harsh opposition by the agribusiness. Though the landed elites did not enjoy hegemony in the public sphere, they relied on strong power alliances to defend their interests. Their congressional arm across different political parties (bancada ruralista) enabled them blocking or voting through

57 Turzi, The Political Economy of Agricultural Booms, 95-96; Robles and Veltmeyer, The Politics of Agrarian Reform in Brazil: The Landless Rural Workers Movement (Social Movements and Transformation), 189-95. 
legislative initiatives. Outside the parliament, large landowners, in alliance with provincial and municipal authorities, successfully used the courts to challenge land expropriations. Most importantly, the PT government sided with export-oriented agribusiness as a revenue-increasing model of development, encouraging its growth with legal and financial incentives. In line with the compromise between political and economic power, Lula even appointed an agribusiness advocate as Minister of Agriculture. Contrary to what one might have expected, the "post-neoliberal" governments empowered the neoliberal agribusiness elite, including soy producers, processors and traders, over the MST's core clientele, the indigenous populations and landless peasants ${ }^{58}$.

\section{CONCLUSION}

Although soy expansions in Manchuria, the US Corn Belt, and the Brazilian savannah differ from each other, they also share some similarities. The concept of commodity frontier provides a comparative framework, which distinguishes two dimensions of capitalist incorporation: extensive incorporation at external frontiers ("broadening") and intensive incorporation at internal frontiers ("deepening"). The investigation has shown that the regional cases positioned in this two-dimensional framework correspond with certain arrangements of material, social, and symbolic elements of farming systems or, as outlined by van der Ploeg, modes of farming: the peasant mode by farming families, involving the co-production of society and nature through application of self-controlled resources; the entrepreneurial mode by farmers, oriented towards flows of inputs (e.g. farm technology) and outputs (e.g. industrial raw products) via factor and product markets; and the capitalist mode by commercial firms, organized by the sole principle of profit-maximization through exploitation of labor and nature ${ }^{59}$.

The interregional comparison relates the Brazilian soy expansion to other cases, revealing a sort of middle-position between the Chinese and US soy

\footnotetext{
58 Turzi, The Political Economy of Agricultural Booms, 95-97; Robles and Veltmeyer, The Politics of Agrarian Reform in Brazil: The Landless Rural Workers Movement (Social Movements and Transformation), 190-94.

59 Jan Douwe van der Ploeg, The New Peasantries: Rural Development in Times of Globalization, 2nd ed. (New York: Routledge, 2018$), 1-5$.
} 
expansions. The Chinese soy expansion from the 1900s to the 1930s resulted almost exclusively from shifts of the external frontier through the expansion of cultivated land, especially after the construction of railroads in Manchuria. The broadening of the soy frontier connected to the peasant mode of Han-Chinese farming: at the material level, it involved family labor, polyculture with crop rotation, and simple technology. At the ideational level, the families and communities followed the conservative mindset of "reluctant pioneers" rather than by a progressive "frontier mentality."

The US soy expansion from the 1930s to the 1970s resulted mainly from shifts of the internal frontier, i.e. the replacement of feed grains and other forage crops by soybeans on already cultivated fields. The deepening of the soy frontier followed by the entrepreneurial mode of Corn Belt farming: at the material level, it involved family and wage labor, corn-soy bi-culture with crop rotation, and the technological package of machinery and agrochemicals. At the ideational level, the farming families followed the logic of enhancing their own standards of living through saving labor and money.

The Brazilian soy expansion from the 1970s to the 2010s combined both modes of frontier shifts that characterized the Chinese and US cases: initially, the boom resulted from extreme shifts of the external frontier from south to north, before the internal frontier also moved ahead through adoption of the (bio-)technological package under tropical conditions. The flexible broadening and deepening of the soy frontier in Mato Grosso corresponded with the capitalist mode of high-tech farming: At the material level, it involved wage labor, mono- or bi-culture, and the technological package of machinery, agrochemicals, and transgenic seeds. At the ideational level, it adopted the colonialist attitude of "frontier mentality" towards peasant and indigenous communities and near-natural biomes.

The soybean more than passively joined the web of actors at the soy frontier; it played a thoroughly active, though paradoxical, role through its potentials and limitations on how human actors can extract value from it ${ }^{60}$. Particularly in the early

${ }^{60}$ Ernst Langthaler, "The Soy Paradox: The Western Nutrition Transition Revisited, 1950-2010," Global Environment 11, no. 1 (2018): 79-104, 
growth phase, which is under competitive pressure from other crops, the plant demands effective combinations of work and technology in the field: manual weeding by family and wage laborers in the Chinese soy expansion; mechanical and chemical control of competing plants by farmers in the US soy expansion; and the application of the technological package of herbicide-resistant transgenic seeds and herbicides purchased from agro-industrial companies in the Brazilian soy expansion. With the gradual replacement of labor by technology, soy farming was more and more disembedded from the regional "socio-nature" and incorporated into global flows of goods, capital and knowledge. The impact of high-tech commodification is most clearly visible in the Brazilian case: the new socio-technical arrangements tended to simplify and cheapen soy farming according to the capitalist logic of value accumulation - without every single step in the growth cycle being completely manipulable and calculable.

Shifts of commodity frontiers were often disruptive and, hence, contested among the actors involved. From these contests, counter-forces to soy expansions gained momentum. The case of Brazil shows these dialectics most clearly: social disruptions, such as dispossessions of smallholders, low wage levels or forms of unfree labor, have led to the emergence of the landless movement as a counter-force to soy expansion at the external frontier. Natural disruptions, such as the large-scale application of agrochemicals, have led to the emergence of herbicide-resistant "superweeds" as a counter-force to soy expansion at the internal frontier. Since these socio-natural counter-forces have partially slowed down the expansion or even contracted soy-based commodity chains, food regime scholars are rather optimistic about a fundamental transition to a socio-naturally sustainable regime ${ }^{61}$. In-depth case studies suggest more pessimism, however, since these counter-forces run the danger of being overridden by well-established political and corporate powers, as revealed for instance by the struggles over soy expansions under "post-neoliberal" governments in Brazil and other South American countries after the turn of the 
century $^{62}$. The degree to which the boom of soy farming in global capitalism and its severe socio-natural burden over past decades will encounter movements directed towards a more sustainable future remains to be $\operatorname{seen}^{63}$.

\section{REFERENCIAS}

Adams, Jane. The Transformation of Rural Life: Southern Illinois, 1890-1990. Chapel Hill: University of North Carolina Press, 1994.

Allen, Douglas W., and Dean Lueck. "Agricultural Contracts." In Handbook of New Institutional Economics, edited by Claude Menard and Mary M. Shirley, 465-90. Berlin, Heidelberg: Springer-Verlag Berlin Heidelberg, 2008.

Anderson, Joseph Leslie. Industrializing the Corn Belt: Agriculture, Technology, and Environment, 1945-1972. DeKalb, Illinois: Northern Illinois University Press, 2009.

Bair, Jennifer. Frontiers of Commodity Chain Research. Stanford, California: Stanford University Press, 2008.

Baletti, Brenda. "Ordenamento Territorial: Neo-Developmentalism and the Struggle for Territory in the Lower Brazilian Amazon." Journal of Peasant Studies 39, no. 2 (2012): 573-98. https://doi.org/10.1080/03066150.2012.664139.

Baraibar Norberg, Matilda. The Political Economy of Agrarian Change in Latin America. Cham: Palgrave Macmillan, 2019.

Bois, Christine M. Du. "Social Context and Diet: Changing Soy Production and Consumption in the United States." In The World of Soy, edited by Christine M. Du Bois, Chee-Beng Tan, and Sidney Mintz, 208-33. illinois: University of Illinois Press, 2008.

---. The Story of Soy. London: Reaktion Books, 2018.

Bois, Christine M. Du, and Sidney Mintz. "Soy." In Encyclopedia of Food and Culture: Volume 3, edited by Solomon H. Katz. New York: Scribner, 2000.

Bois, Christine M. Du, and Ivan Sergio Freire de Sousa. "Genetically Engineered Soy." In The World of Soy, edited by Christine M. Du Bois, Chee-Beng Tan, and Sidney Mintz, 74-98. illinois: University of Illinois Press, 2008.

Cáceres, Daniel M. "Accumulation by Dispossession and Socio-Environmental Conflicts Caused by the Expansion of Agribusiness in Argentina." Journal of Agrarian Change 15, no. 1 (2015): 116-47. https://doi.org/10.1111/joac.12057.

\footnotetext{
62 Lapegna, Soybeans and Power; Karin Fischer and Ernst Langthaler, "Soy Expansion and Countermovements in the Global South: A Polanyian Perspective," in Capitalism in Transformation, ed. Roland Atzmüller et al. (Cheltenham, Northampton, MA: Edward Elgar Publishing, 2019), 21227.

${ }^{63}$ Ernst Langthaler and Elke Schüßler, "Commodity Studies with Polanyi: Disembedding and Re-Embedding Labour and Land in Contemporary Capitalism," Österreichische Zeitschrift Für Soziologie 44, no. 2 (2019): 209-23, https://doi.org/10.1007/s11614-019-00339-2.
} 
Carlson, Jon D. "Broadening and Deepening: Systemic Expansion, Incorporation and the Zone of Ignorance." Journal of World-Systems Research 7, no. 2 (2001): 225-63. https://doi.org/10.5195/jwsr.2001.180.

Carstensen, Lisa. "'Modern Slave Labor' in Brazil at the Intersection of Production, Migration and Resistance Networks." In On Coerced Labor: Work and Compulsion after Chattel Slavery, edited by Marcel M. van der Linden and Magaly Rodríguez García, 267-90. BRILL, 2016. https://doi.org/10.1163/9789004316386_013.

Chao, Kang. The Economic Development of Manchuria. Ann Arbor, MI: University of Michigan Press, 1983. https://doi.org/10.3998/mpub.19151.

Connor, David J., Robert S. Loomis, and Kenneth G. Cassman. Crop Ecology: Productivity and Management in Agricultural Systems. 2nd ed. Cambridge: Cambridge University Press, 2011.

Costa, Patricia Trindade Maranho, and International Labour Organisation (ILO)). Fighting Forced Labour: The Example of Brazil. Geneva: International Labour Office, 2009.

Deasy, G. F. "The Soya Bean in Manchuria." Economic Geography 15, no. 3 (1939): 30310. https://doi.org/10.2307/141549.

Food and Agriculture Organization. "Faostat," 2020. http://www.fao.org/faostat.

Fischer, Karin, and Ernst Langthaler. "Soy Expansion and Countermovements in the Global South: A Polanyian Perspective." In Capitalism in Transformation, edited by Roland Atzmüller, Brigitte Aulenbacher, Ulrich Brand, Fabienne Décieux, Karin Fischer, and Birgit Sauer, 212-27. Cheltenham, Northampton, MA: Edward Elgar Publishing, 2019.

Garrett, Rachael D., and Lisa L. Rausch. "Green for Gold: Social and Ecological Tradeoffs Influencing the Sustainability of the Brazilian Soy Industry." The Journal of Peasant Studies 43, no. 2 (2016): 461-93. https://doi.org/10.1080/03066150.2015.1010077.

Gottschang, Thomas, and Diana Lary. Swallows and Settlers: The Great Migration from North China to Manchuria. Ann Arbor, MI: University of Michigan Press, 2000.

Gottschang, Thomas R. "Economic Change, Disasters, and Migration: The Historical Case of Manchuria." Economic Development and Cultural Change 35, no. 3 (1987): 461-90.

Hall, Thomas D. "Puzzles in the Comparative Study of Frontiers: Problems, Some Solutions, and Methodological Implications." Journal of World-Systems Research 15, no. 1 (2009): 25-47. https://doi.org/10.5195/jwsr.2009.332.

Harnoncourt, Julia. Unfreie Arbeit: Trabalho Escravo in Der Brasilianischen Landwirtschaft. Wien: Promedia Verlagsges, 2018. 
Haystead, Ladd, and Gilbert C. Fite. The Agricultural Regions of the United States. London: Methuen \& Co., 1955.

Hopkins, Terence K., and Immanuel Wallerstein. "Commodity Chains in the WorldEconomy Prior to 1800." Review (Fernand Braudel Center) 10, no. 1 (1986): 157-70. https://www.jstor.org/stable/40241052.

Hudson, John C. Making the Corn Belt: A Geographical History of Middle-Western Agriculture. Bloomington, Indiana: Indiana University Press, 1994.

IBGE. "Censo Agropecuário 2006: Brasil, Grandes Regiões e Unidades Da Federação." Rio de Janeiro, 2006. https://biblioteca.ibge.gov.br/visualizacao/periodicos/51/agro_2006.pdf.

Imperial Maritime Customs (China). The Soya Bean of Manchuria. Shanghai: Inspector General of Customs, 1911.

Ioris, Antonio Augusto Rossotto. Agribusiness and the Neoliberal Food System in Brazil: Frontiers and Fissures of Agro-Neoliberalism. Abingdon, Oxon / New York, NY: Routledge, Taylor \& Francis Group, 2018.

Klein, Herbert S., and Francisco Vidal Luna. Feeding the World: Brazil's Transformation into a Modern Agricultural Economy. Cambridge: Cambridge University Press, 2018.

Komlosy, Andrea. "Kapitalismus Als Frontier: Die Verwandlung von Kulturen in Rohstofflieferanten." In Rohstoffe Und Entwicklung. Aktuelle Auseinandersetzungen Im Historischen Kontext, edited by Karin Fischer, Johannes Jäger, and Lukas Schmidt. Wien: New academic press, 2016.

Langenberg, Johannes. Die Bedeutung Der Sojabohne in Der Weltwirtschaft. Pinneberg: Beig, 1929.

Langthaler, Ernst. "Gemüse Oder Ölfrucht? Die Weltkarriere Der Sojabohne Im 20. Jahrhundert." In Umkämpftes Essen: Produktion, Handel Und Konsum von Lebensmitteln in Globalen Kontexten, edited by Cornelia Reiher and Sarah Ruth Sippel, 41-66. Göttingen: Vandenhoeck \& Ruprecht, 2014. https://doi.org/10.13109/9783666301704.41.

---. "The Soy Paradox: The Western Nutrition Transition Revisited, 1950-2010." Global Environment 11, no. 1 (2018): 79-104. https://doi.org/10.3197/ge.2018.110105.

Langthaler, Ernst, and Elke Schüßler. "Commodity Studies with Polanyi: Disembedding and Re-Embedding Labour and Land in Contemporary Capitalism." Österreichische Zeitschrift Für Soziologie 44, no. 2 (2019): 209-23. https://doi.org/10.1007/s11614-019-00339-2.

Lapegna, Pablo. Soybeans and Power. Oxford University Press, 2016. https://doi.org/10.1093/acprof:oso/9780190215132.001.0001. 
McMichael, Philip. Food Regimes and Agrarian Questions. Rugby, Warwickshire, United Kingdom: Practical Action Publishing, 2013. https://doi.org/10.3362/9781780448794.

Moore, Jason W. Capitalism in the Web of Life: Ecology and the Accumulation of Capital. London, New York: Verso, 2015.

---. "Sugar and the Expansion of the Early Modern World-Economy: Commodity Frontiers, Ecological Transformation, and Industrialization." Review (Fernand Braudel Center) 23, no. 3 (2000): 409-33. https://www.jstor.org/stable/40241510.

Ofstehage, Andrew. "Farming Is Easy, Becoming Brazilian Is Hard: North American Soy Farmers' Social Values of Production, Work and Land in Soylandia." The Journal of Peasant Studies 43, no. 2 (2016): 442-60. https://doi.org/10.1080/03066150.2014.998651.

Patel, Raj. Stuffed and Starved: Markets, Power and the Hidden Battle for the World Food System. London: Portobello Books, 2008.

Pérez, Mamerto, Timothy A. Wise, and Sergio Schlesinger. "The Promise and the Perils of Agricultural Trade Liberalization: Lessons from Latin America," 2008.

Ploeg, Jan Douwe van der. The New Peasantries: Rural Development in Times of Globalization. 2nd ed. New York: Routledge, 2018.

Prodöhl, Ines. "From Dinner to Dynamite: Fats and Oils in Wartime America." Global Food History 2, no. 1 (2016): 31-50.

https://doi.org/10.1080/20549547.2016.1138366.

---. "Versatile and Cheap: A Global History of Soy in the First Half of the Twentieth Century." Journal of Global History 8, no. 3 (2013): 461-82. https://doi.org/10.1017/S1740022813000375.

Reardon-Anderson, James. "Land Use and Society in Manchuria and Inner Mongolia during the Qing Dynasty." Environmental History 5, no. 4 (2000): 503-30. https://doi.org/10.2307/3985584.

---. Reluctant Pioneers: China's Expansion Northward, 1644-1937. Stanford, California: Stanford University Press, 2005.

Robles, Wilder, and Henry Veltmeyer. The Politics of Agrarian Reform in Brazil: The Landless Rural Workers Movement (Social Movements and Transformation). New York, NY: Palgrave Macmillan, 2015.

Roth, Matthew. Magic Bean: The Rise of Soy in America. Lawrence, Kansas: University Press of Kansas, 2018.

Schönardie, Paulo Alfredo. Bäuerliche Landwirtschaft Im Süden Brasiliens: Historische, Theoretische Und Empirische Studie Zu Ernährungssouveränität, Modernisierung, 
Wiederbelebung Und Staatsfunktion. München: Oekom Verlag, 2013.

SILVA, Claiton Márcio da. "Entre Fênix e Ceres: A Grande Aceleração e a Fronteira Agrícola No Cerrado." Varia Historia 34, no. 65 (2018): 409-44. https://doi.org/10.1590/0104-87752018000200006.

Sousa, Ivan Sergio Freire de, and Rita de Cássia Milagres Teixera Vieira. "Soybeans and Soyfoods in Brazil, with Notes on Argentina: Sketch of an Expanding World Commodity." In The World of Soy, edited by Christine M. Du Bois, Chee-Beng Tan, and Sidney Mintz, 234-56. illinois: University of Illinois Press, 2008.

Sowa, Ivan Sergio Freire de, and Lawrence Busch. "Networks and Agricultural Development: The Case of Soybean Production and Consumption in Brazil." Rural Sociology 63, no. 3 (1998): 349-71. https://doi.org/10.1111/ruso.1998.63.3.349.

Stewart, John R. "The Soya Bean and Manchuria." Far Eastern Survey 5, no. 21 (1936): 221-26. https://doi.org/10.2307/3021359.

Sun, Kungtu C. The Economic Development of Manchuria in the First Half of the Twentieth Century. Harvard University Asia Center, 1969. https://doi.org/10.2307/j.ctt1tg5hhd.

Turner, Frederick J. The Frontier in American History. Norderstedt, Germany: BoD Books on Demand, 2012.

Turzi, Mariano. The Political Economy of Agricultural Booms. Cham: Springer International Publishing, 2017. https://doi.org/10.1007/978-3-319-45946-2.

US Bureau of the Census. "Census of Agriculture 1964 - Iowa." Washington, DC: US Government Printing Office, 1967.

US Department of Agriculture. "National Agricultural Statistics Service," 2019. http://www.nass.usda.gov.

Vorley, Bill. Food, Inc.: Corporate Concentration from Farm to Consumer. London: UK Food Group, 2003.

Whayne, Jeannie M. A New Plantation South: Land, Labor, and Federal Favor in Twentieth-Century Arkansas. Charlottesville, VA: University Press of Virginia, 1996.

Willebald, Henry, and Javier Juambeltz. "Land Frontier Expansion in Settler Economies, 1830-1950: Was It a Ricardian Process?" In Agricultural Development in the World Periphery, edited by Vicente Pinilla and Henry Willebald, 439-66. Cham: Springer International Publishing, 2018. https://doi.org/10.1007/978-3319-66020-2_17.

Wisconsin Historical Society, International Harvester Company Film Collection, AC 741. "Soybeans for Farm and Industry." Accessed October 1, 2019. http://archive.org/details/0914_Soybeans_for_Farm_and_Industry_00_21_4 
Broadening and Deepening: Soy Expansions in a World-Historical Perspective

Ernst Langthaler

$4 \_29$.

Wolff, David. "Bean There: Toward a Soy- Based History of North East Asia." The South Atlantic Quarterly, 99, no. 1 (2000): 241-52. 


\section{Ampliación y Profundización: Expansiones de la Soja desde una Perspectiva Histórica Mundial}

\section{RESUMEN}

Este artículo evalúa la expansión de la soja en América del Sur desde una perspectiva histórica mundial, comparando el caso de Brasil con los casos de China y Estados Unidos. Para este propósito, aplica el concepto de frontera de mercancías, involucrando modos internos y externos de incorporación capitalista. La expansión de la soja china (1900-1930) muestra un cambio predominante de la frontera externa, asociado con el modo de cultivo campesino. La expansión de la soja en los Estados Unidos (1930-1970) representa un cambio predominante en la frontera interna, conectado con el modo empresarial de la agricultura. La expansión de la soja brasileña (1970-1910) revela una combinación flexible de cambios fronterizos extensivos e intensivos, que se corresponden con el modo de cultivo capitalista. Estos auges de los productos básicos fueron impulsados no solo por los estados nacionales, las empresas capitalistas y los movimientos sociales, sino también por los potenciales y las limitaciones de la planta de soja en sí misma. Los cambios en las fronteras de los productos básicos a menudo se interrumpían para la sociedad y la naturaleza y, por lo tanto, se disputaban entre diversos actores, tanto humanos como no humanos.

Palabras Clave: Soja; Expansión de la Soja; Frontera de Productos Básicos; Modo de Cultivo; China, Estados Unidos, Brasil. 